\title{
MONITORING ON FOREST ECOSYSTEMS BY USING SPACE- TEMPORAL ANALYSIS OF DIFFERENT TYPES AEROSPACE DATA
}

\author{
Andrei Stoyanov, Denitsa Borisova
}

\begin{abstract}
The following work presents results derived by space-temporal analysis of different types of aerospace data for environmental monitoring on the dynamics of the condition of the forest vegetation.

Different indices (NDVI, NDWI) and indicators have been used for territories occupied by different types of forest ecosystems. A comparative analysis between optical and radar images have been conducted and results about the degree of correlation between the different generated indices from the tested areas are presented.

Based on the performed different analysis and surveys and the results derived from them, an evaluation can be done for the following: for which territories occupied by specific forest vegetation are the most sensitive indices during the monitoring.

The derived results could be used for monitoring and ecological assessment on forest resources management in regional and national action plans.
\end{abstract}

Keywords: forest monitoring, satellite images, NDVI, SAR, environmental monitoring

\section{INTRODUCTION}

The researched object in the current research is Natural Park "Sinite Kamani". It is located in the southeast part of Bulgaria in Sliven mountain, the Mount of Stidovo and the Mount of Grebenets, which are parts from the south ridge of Eastern Stara Planina mountain. The Natural park "Sinite Kamani" is situated on the south slopes of Eastern Stara planina mointain (Udvoi Planina- Chatal Balkan) above Sliven town. It is located between the geographical coordinates $26^{\circ} 10^{\prime}$ and $26^{\circ} 60^{\prime}$ eastern longtitude and $42^{\circ} 30^{\prime}$ and $42^{\circ} 50^{\prime}$ north latitude [1].

These are: territories occupied mainly from broadleaved forest vegetation; territories occupied from coniferous forest vegetation and territories occupied by mixed type of forest vegetation. The monitoring of the forest vegetation and the control of the condition of the forest health is from the utmost importance for the application of the forest planning, management and conservation. The monitoring of the forest coverage is from essential importance for maintaining of enough forest coverage and cultivation of different forest types in support of social, economic and ecological purposes, directly connected to the forest managements in the aspect of a specific region or country.

Multi-purposed thematic cartography and its main goals linked to determining the scale of the forest and classifying the forest types is supported by the Remote Sensing (RS). The data used by RS helps for improvement of information and knowledge base for disturbance and borders of the forest vegetation. The yearly upgrading of spatial, spectral and radiometric capability of the satellite sensors is of peculiar importance in some areas of environment and forest management [2].

The data derived from RS - from sensors capturing electromagnetic energy, situated on earth, air and satellite platforms have some essential characteristics - high geospatial resolution, broad spatial range and short period of acquisition of data from the same territory. The data from RS and the opportunity of it to be easily integrated in the Geographical Information Systems (GIS) and analyzed together with information from other sources, allows generation of effective applications for forest management [3].

Respective for each of the zones, satellite images from optical and microwave spectrum of EMR (electro-magnetic radiation) have been chosen in a specific temporal interval $\left(\mathrm{t}_{1}, \mathrm{t}_{2}, \mathrm{t}_{3} \quad \ldots\right)$. Orthophotographic images of the chosen territories from the existing national aerophoto capturing of Republic of Bulgaria have been used. Indices for vegetation and moisture quantity in the tree canopies have been generated.

The goal of the conducted research is making of space-temporal analysis of the disturbance and the condition of the forest resources on the territory of Natural Park Sinite Kamani via RS methods and vegetation index NDVI (Normalized Differential Vegetation Index).

The usage of three satellite multispectral images (scenes) from 1990, 2000 and 2015, provides us with the opportunity to look at them as temporal points, moments, which have preserved in themselves transitory condition of the forest disturbance. 


\section{TASKS}

- Interpretation of the Landsat scenes by using specific combinations of spectral channels and defining the scale of the forest massifs in each of the three temporal points;

- Analysis of the vegetation condition in the forest massifs through calculation of NDVI index for the three temporal points;

- Conduction of comparative analysis on the changes in the vegetation condition through analysis of the NDVI values;

- Exploration and comparative analysis of the changes in the forest disturbance for each of the temporal points;

- Analysis of the development of the forest resources on the territory of the natural park, as well as tendencies in the disturbance and condition of the forests.

\section{METHODOLOGY}

In the current research temporal and spatial analysis has been made with application of the methods of GIS and RS, based on satellite images. Products of Landsat 5 TM, Landsat ETM+ and Landsat OLI/TIRS have been chosen.

Table 1. Combination of channels based on which NDVI was generated

\begin{tabular}{|l|c|c|}
\hline \multicolumn{1}{|c|}{ Sensor } & Red & Near IR \\
\hline Landsat 5 TM & $0,66 \mu \mathrm{m}$ & $0,825 \mu \mathrm{m}$ \\
\hline Landsat 7 ETM + & $0,66 \mu \mathrm{m}$ & $0,825 \mu \mathrm{m}$ \\
\hline Landast 8 OLI_TIRS & $0,655 \mu \mathrm{m}$ & $0,865 \mu \mathrm{m}$ \\
\hline
\end{tabular}

The suggested methodology includes:

- Determining the area of interest. This would be the territory shown by the three images. The extraction of this polygon is done by simple spatial algebra - calculation of a new raster;

- Spectral analysis, decoding and mapping of the territories occupied by forests in the area of interest. For more precise results, calculation of the vegetation index is done only in the scope of the spatial borders in the area of interest (the borders of the natural park).

- Comparative analysis of the changes in the periods between 1990-2000, 2000-2015 and 19902015. The principle of extraction of one main layer, which is a section of two layers of forest disturbance has been used. This layer would be called „example”. The example is the territory which throughout the whole temporal period has not changed and has remained covered with forest. After that, we extract a layer which contains polygons and has changed land cover. In this layer we study the alteration of the forest disturbance for the 25 year period;

- Tracing of the alteration of the forest disturbance through generating a vegetation index (NDVI).

Normalized Differential Vegetation Index (NDVI) gives us the opportunity to estimate not only the current forest health condition, but also to give a potential prognosis for their future disturbance and health. The chosen input data and methodology are a small part of the numerous applications of satellite systems for monitoring and environmental management. [4]

NDVI is one of the most successful of the many made experiments for quick and easy identification of the vegetation areas and their condition. At this moment, it is one of the most accessible indices for estimation of the active photosynthetic vegetation based on multispectral satellite data [4].

To estimate the condition of the vegetation on part of the land cover, the following needs to be examined: the intensity of the sun radiance reflection in the visible and near infrared (NIR) range of the EMR spectrum from the forest leaves. As it can be seen through the glass prism, the light is comprised of a few different colours. Each of them has different wavelength and they form the spectrum of the sun radiance. When the earth objects are illuminated, part of the EMR (light) is absorbed and another part, with a specific wavelength is reflected from them. The pigment of the leaves called chlorophyll strongly absorbs light in the range between 0.4 and 0.7 $\mu \mathrm{m}$ and uses it for photosynthesis [5].

The structure of the leaves mass, on the other hand is strongly reflected in the near infrared zone (from 0.7 to $1.1 \mu \mathrm{m}$ ). The more leaves mass the vegetation has, the bigger the amplitude between the reflected energy in the visible spectrum and the reflected energy in the near infrared spectrum [5].

$$
N D V I=\frac{\rho_{N I R-} \rho_{R E D}}{\rho_{N I R+} \rho_{R E D}}
$$

In this formula, RED and NIR serve for measurement of the spectrum reflection, derived respectively in the red and near infrared range. The spectral reflectance ratio between the reflected and the input amount of radiation in every of the spectral 
range accept the value of $0: 1$. The NDVI varies with values between -1 and +1 . If the territory is not occupied by vegetation, then the value of the index is around 0 . Value close to +1 shows thick vegetation and high density of the leaves. In the current research, the green visible and near infrared channel of the platforms Landsat 5, 7 and 8 are shown.

The used in the following work images are from three different sensors (TM, ЕTM+ и OLI), each of these sensors has its own specific characteristics. In Tabl.1 spectral channels for each of the base instruments, on top of which is generated NDVI, are shown. On Fig. 3, 5 and 7 results are sown from the NDVI classification of the three satellite images used.

\section{RESULTS}

On the first two figures, images are shown in the real colours in RGB for the first two temporal points.

\section{Composite satellite image of the area of interest}

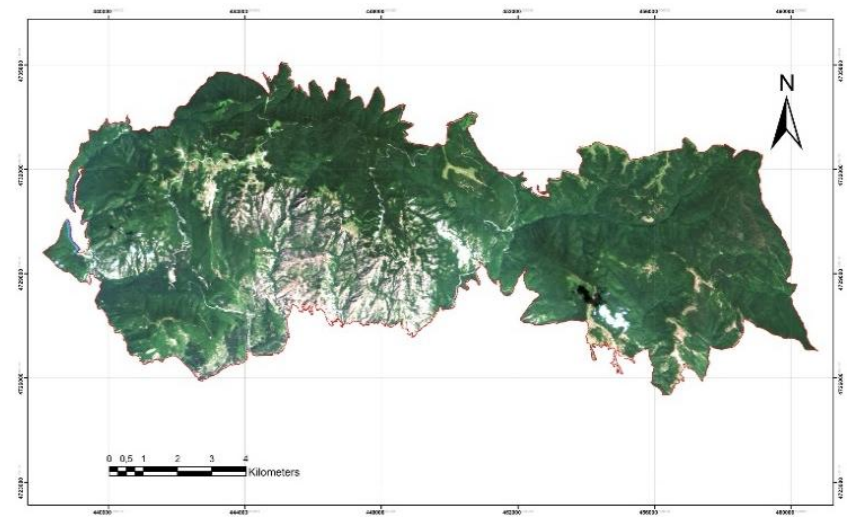

Fig.1. Composite satellite image (bands: 4-3-2) from Landsat 7 ETM 29.07.1990 of territory of the Natural park "Sinite Kamani"

\section{NDVI generated images}

On Fig. 3, 4, 5, 6, 7 and 8 are shown results from the controlled classification made on the base NDVI for the different images and 4 classes of objects have been classified: water territories, grassland areas, rocks, and anthropogenic objects, all of which have been classified as "others" and broad-

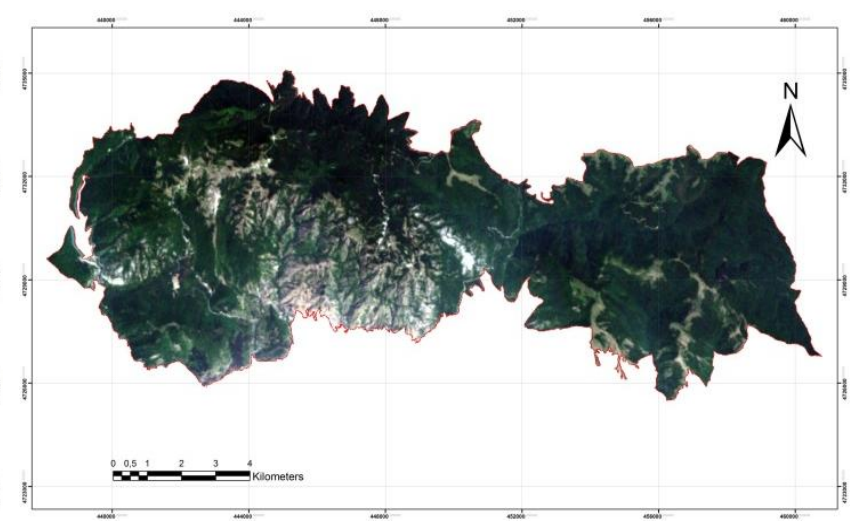

Fig. 2. Composite satellite image (bands: 4-3-2) from Landsat 7 ETM 14.06.2000 of territory of the Natural park "Sinite Kamani"

leaved forests and coniferous. "Others" means a lack of forest vegetation.

The generated NDVI index has been subjected under control classification. Through analysis of the chosen area of interest, for which the forest coverage can be clearly defined, the values of the interested types of land cover had been summed (Table 2).

Table 2. Classification of land cover types

\begin{tabular}{|l|c|}
\hline \multicolumn{1}{|c|}{ Land cover type } & NDVI values \\
\hline water territories & $-0,15-0,55$ \\
\hline $\begin{array}{l}\text { grassland areas, rocks, and } \\
\text { anthropogenic objects }\end{array}$ & $0,55-1,9$ \\
\hline Coniferous trees & $1,9-3,5$ \\
\hline broad-leaved forests & above 3,5 \\
\hline
\end{tabular}




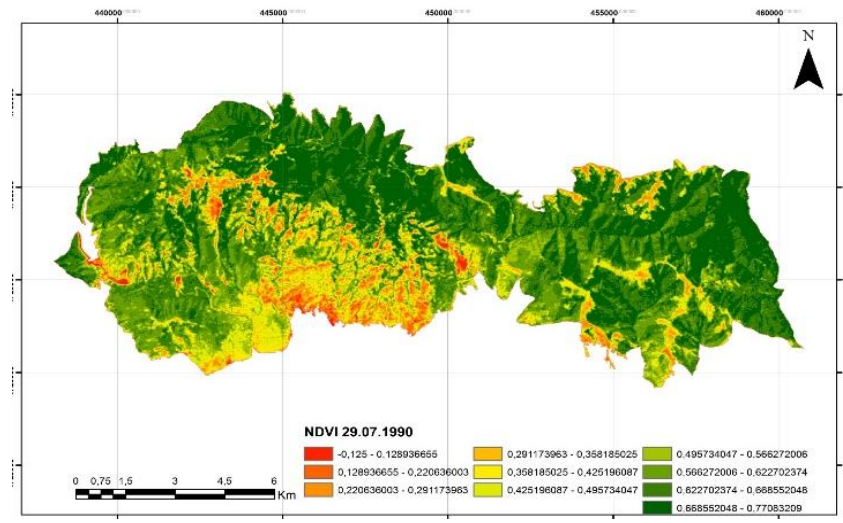

Fig. 3. Thematic maps of the NDVI values of territory of the Natural park "Sinite Kamani" from 29.07.1990

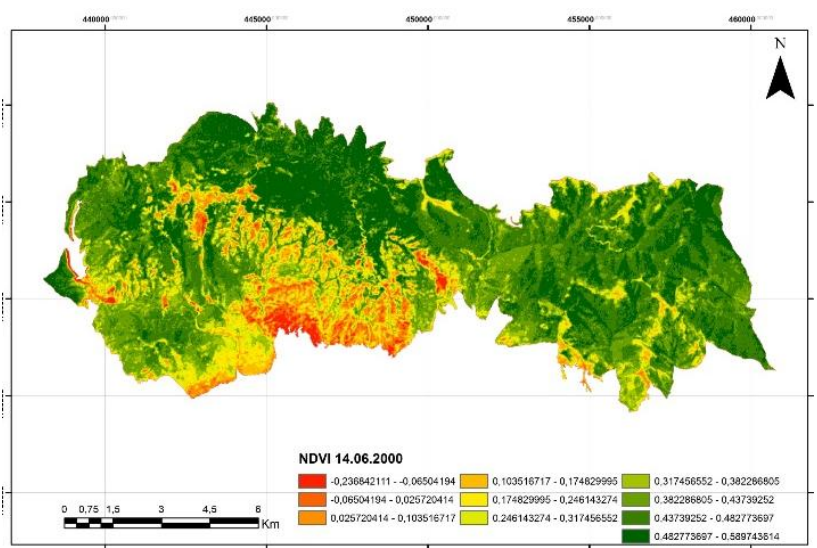

Fig. 5. Thematic map of the NDVI values of territory of the Natural park "Sinite Kamani” from 14.06.2000

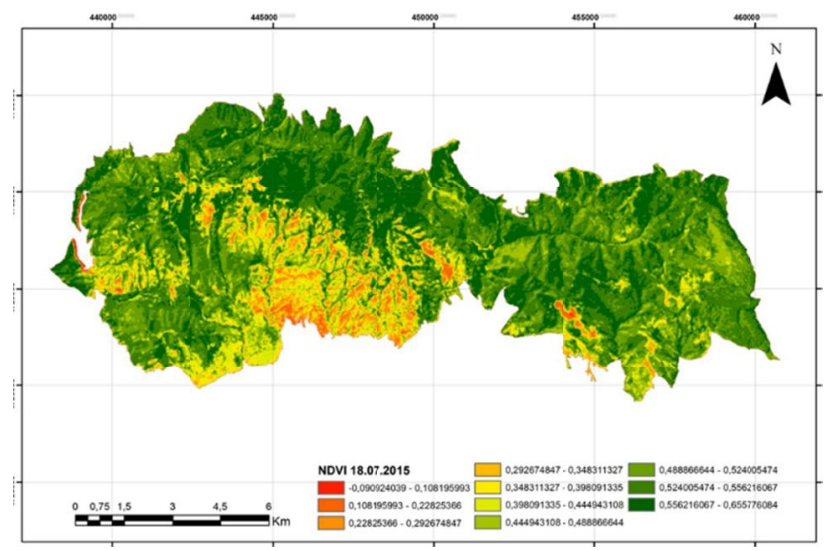

Fig. 7. Thematic map of the NDVI values of territory of the Natural park "Sinite Kamani” from 18.07.2015

On Fig. 5 and 6 the controlled classification based on NDVI index of the Enhanced Thematic Mapper sensor image from 14.06 .2000 is shown. The

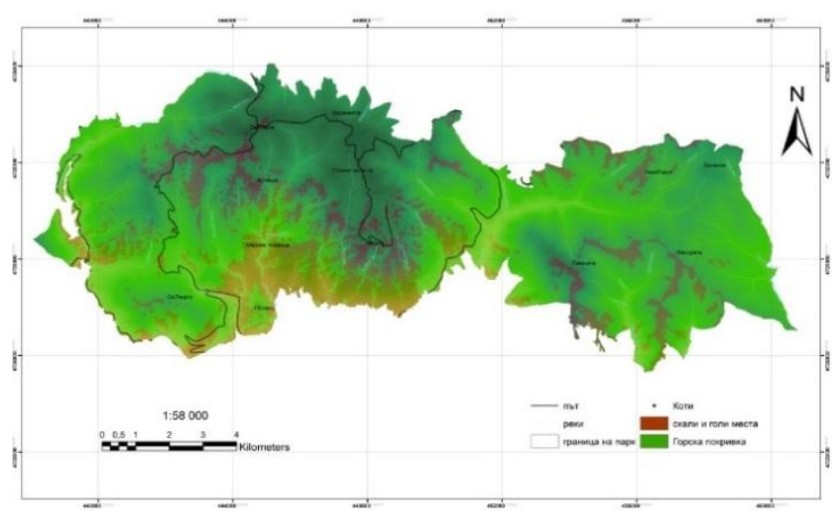

Fig. 4. Thematic maps of the Forest Vegetation Disturbance of territory of the Natural park "Sinite Kamani” from 29.07.1990

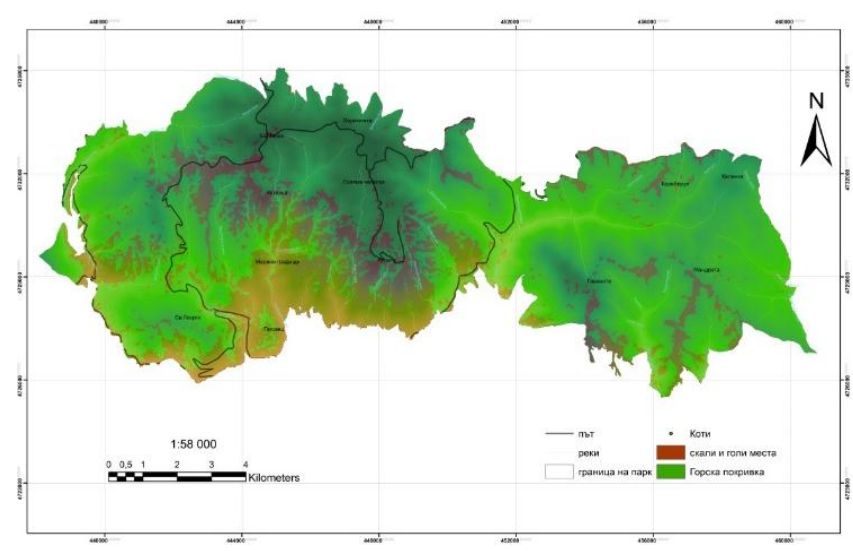

Fig. 6. Forest Vegetation Disturbance of territory of the Natural park "Sinite Kamani" from 14.06.2000

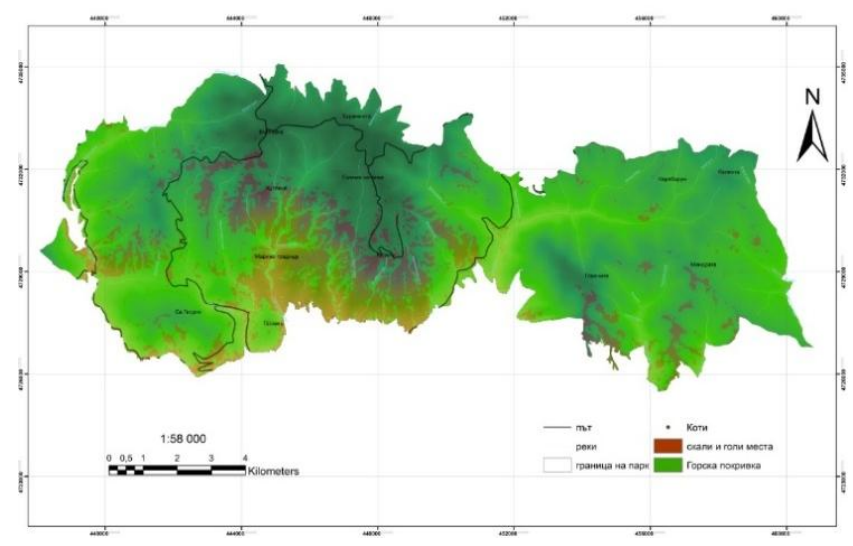

Fig. 8. Forest Vegetation Disturbance of territory of the Natural park "Sinite Kamani" from 18.07.2015

classification has been done accordingly to respectively the described criteria in Table 2 . The same had been done for the OLI_TIRS image 
from 18.07.2015 (Fig. 7, 8). Generally, the forest disturbance kept the same tendencies as for the previously considered period, but nevertheless on that images, parts of the "other" type which had been "removed" by forest vegetation, can be seen.

The changes in the forest disturbance, could be separated mainly in two directions: decreasing or increasing the territory occupied by forest cover. These two processes could be in benefit of other type of forest vegetation, or in benefit of other types of land cover

For the first studied sub-period 1990-2000, there are no major changes that had been occurred. Decreasing of forest vegetation in areas between $300-800 \mathrm{~m}$ above sea level could be localized in south western parts of the park. In the upper range (above $800 \mathrm{~m}$ ), on separately places in centuries-old forests of beech (Fagus salvatica), zones of deforestation could be noticed in the eastern part of the Natural park. These are directly linked with creating a new forest pathway or some logging made during the period. Increasing of forest vegetation has been observed in the following places: area of "Gavanite", area of "Ruins", area of "Daula" and in a very little degree around the highest peak in Eastern Stara Planina - Bulgarka (1181m). In these places the grasslands are reduced in the benefit of forest vegetation.

For the second studied sub-period 2000-2015, there are no also major changes that had been occurred. The zones of deforestation are observed: in the rocky region under the peak of "Golyama Chatalka" which is directly connected to the small fire that had broken out in the summer of 2012; the region of "Bozhura" closed to the eastern border of the park and in the region of "Sotirska river", whereas a whole area of bare land could be distinguished. Increasing of forest vegetation has been observed, mainly, in the lower parts of the park territory and along the valleys of rivers "Novoselska" and "Manastirska", and there were some increase around the regions of "Chukata", "Gavanite" and "Karakyutyuk" (Fig. 9, 10).

A tendency of forest vegetation increase in the higher parts of the mountain has been observed for the studied period of 25 years (1990-2015). The process of deforestation prevails mainly in the lower rocky parts or the studied territory, around the river valleys, in the regions where new cuttings had been done. A change of one land cover type into another had been observed. There is a whole tendency of densing the forest vegetation on the territory of the park, as for some separate regions the forest reduce had been occurred (Fig. 11).

For better visual interpretation and forest geometry to be outlined composite radar images of the Natural park "Sinite Kamani" are used (see Fig. 12).

By conducted n-D Spatial Analysis a good correlation between two indices NDVI (Normalized Differential Vegetation Index) and NDWI (Normalized Differential Water Index) are observed (see Fig. 13).

\section{Change Detection analysis (subperiods)}

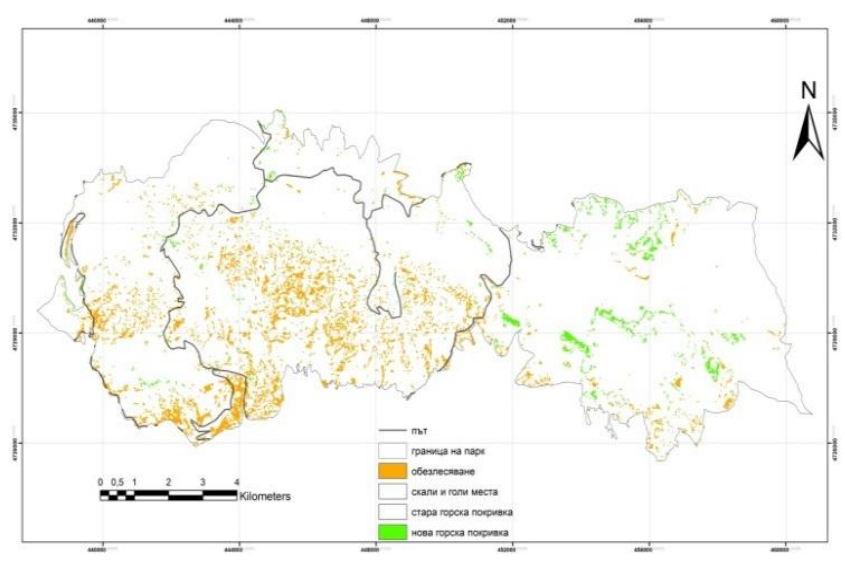

Fig. 9. Change detection map 1990-2000

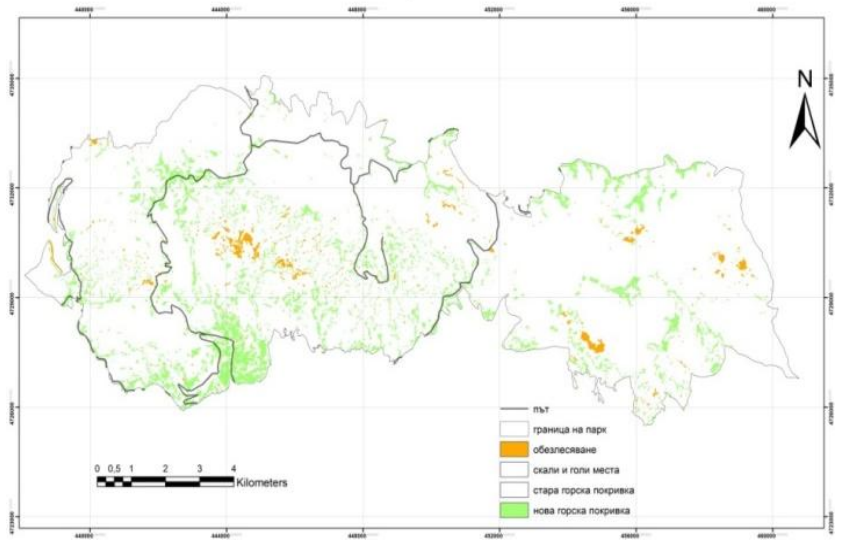

Fig. 10. Change detection map 2000-2015 


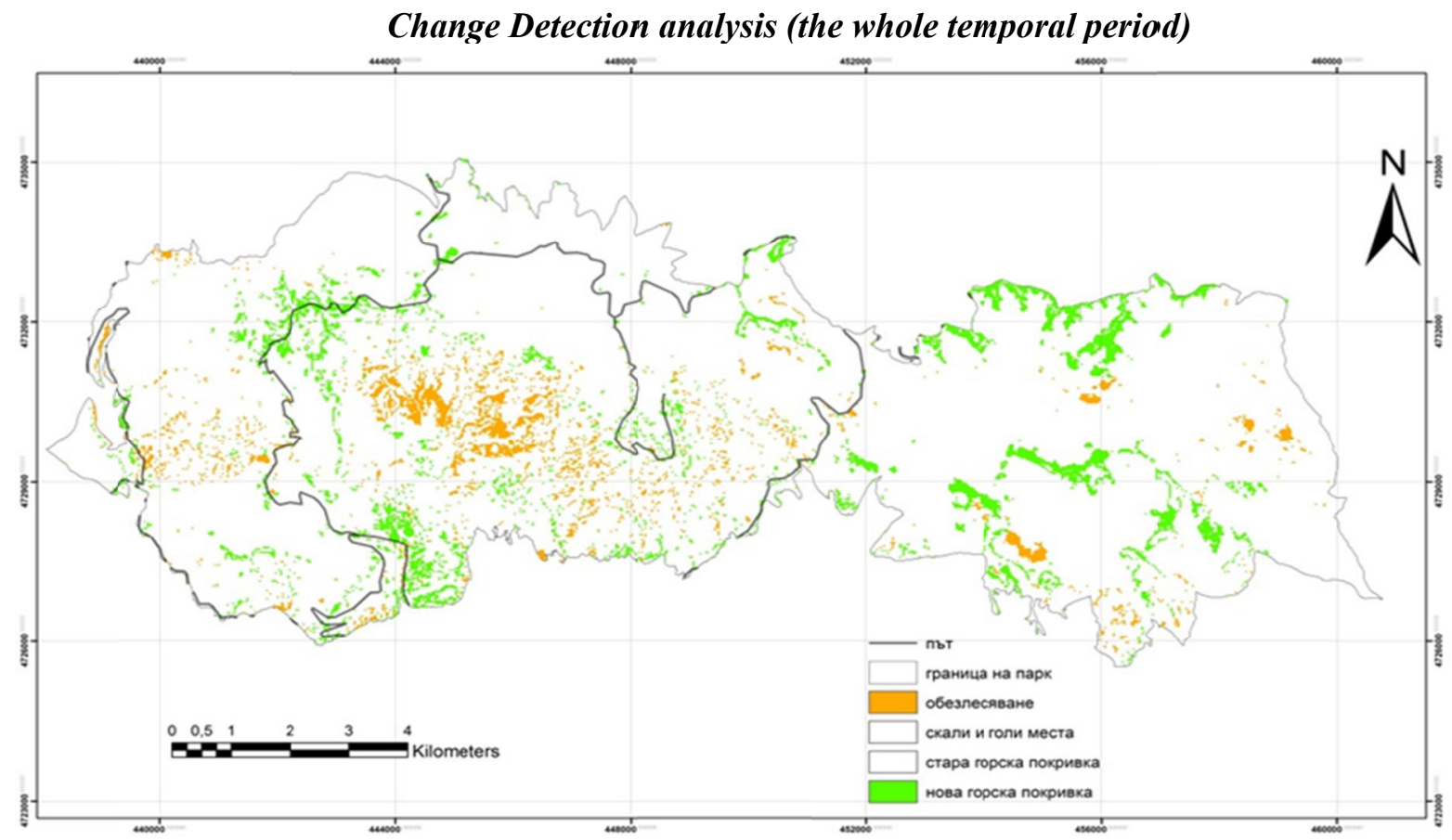

Fig. 11. Change detection map 1990-2015
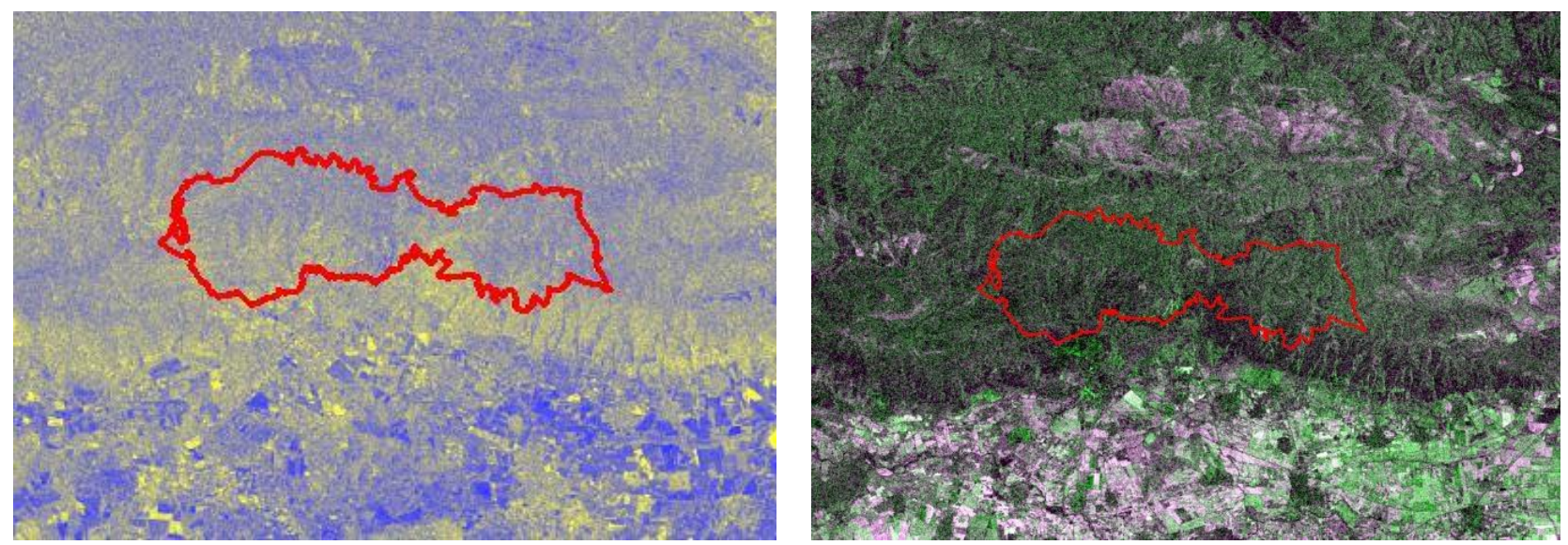

Fig. 12. Radar images of the Natural park "Sinite Kamani"
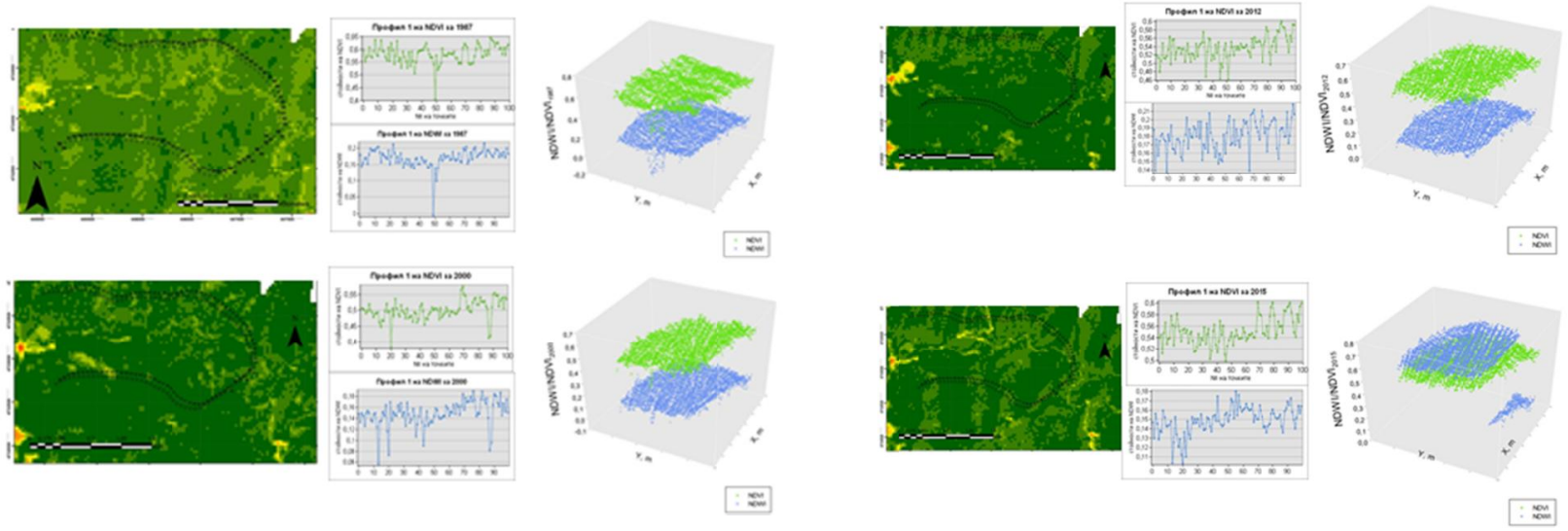

Fig. 13. n-D Spatial Analysis for two indices: NDVI (Normalized Differential Vegetation Index) and NDWI (Normalized Differential Water Index) (1987-2015) 


\section{CONCLUSION}

Through specific combination of spectral channels, the range of the forest vegetation has been determined for each of the three temporal points. Comparative analysis of forest disturbance changes has been done. On the basis of spectral data from the red and NIR channels and NDVI generated values, the condition of forest vegetation has been assessed for all temporal points. Depending on the particular task, the use of vegetation indices gives objective quantitative information about green biomass which can be interpreted numerical, graphically and visually (as image)

As a reference the current research could serves as a good base upon which in future environmental assessments could be generated for needs of forest management and forest conservation. Through the collecting of satellite data from different sensors, after some period of time, an upgrade of the current research by adding more temporal points could be done. It will allow assessment the dynamics of specific type of change detection to be done.

The conducted research explored one major problem of forest monitoring and management and namely is the assessment conduction of forest resources. This assessment had been done by the use of Earth Observation systems, Remote Sensing data, and GIS for analyzing, modeling and generalizing the forest disturbance.

\section{REFFERENCES}

1. Natural Park "Blue Stones", http://dppsk.org/sinite-kamani/priroda-klimat/ [Retrieved May 28, 2017]

2. Richards A., Xiuping, J., Remote Sensing Digital Image Analysis

3. Gates, D. M., Biophysical Ecology, SpringerVerlag, New York, 1980, p. 611

4. Павлова, А., Недков, Р., Приложение на различни вегетационни индекси по отношение на физиологията на горскте екосистеми и климатичните сезони. - SES 2005 Scientific Conference "SPACE, ECOLOGY, SAFETY", Varna, Bulgaria 10- 13 June 2005, c. 263-268

5. Свейн, Ф., Дейвис, Ш., Дистанционное зондирование: Количественый подход, Москва “Недра", 1983, стр. 239-249.

\title{
МОНИТОРИНГ НА ГОРСКИ ЕКОСИСТЕМИ С ИЗПОЛЗВАНЕ НА ПРОСТРАНСТВЕНО-ВРЕМЕВИ АНАЛИЗ НА РАЗЛИЧНИ ТИПОВЕ АЕРОКОСМИЧЕСКИ ДАННИ
}

\author{
Андрей Стоянов, Деница Борисова
}

\begin{abstract}
Резюме: В настоящата работа са представени резултати получени от пространстевно времеви анализ на различни видове аерокосмически данни за екомониторинг на динамиката на състоянието на горската растителност Използвани са разлчни индекси (NDVI, NDWI) и показатели за територии заети от различни типове горски екосистеми. Извършен е сравнителен анализ на оптични и радарни сателитни изображения и са представени резултати за степента на корелация между различните индекси и показатели от различните тестови участъци. На базата на извършените различни анализи и изследвания и получените съответно от тях резултати може да бъде направена оценка за кои територии заети от даден вид горска растителност кои показатели са найчувствителни при извършване на мониторинг. Получените резултати могат да бъдат използвани за мониторинг и екологична оценка при управление на горските ресурси, в регионалните и националните планове.
\end{abstract}

Ключови думи: горски екосистеми, спътникови изображения, NDVI, SAR, екомониторинг

Andrei Stoyanov, Denitsa Borisova

Space Research and Technology Institute - Bulgarian Academy of Sciences

1113, Sofia, „Acad. Georgi Bonchev”str., bl.1

e-mail: andreiIKIT@space.bas.bg

Андей Стоянов, Деница Борисова

Институт за космически изследвания и технологии - БАН

секция „Аерокосмическа информация“

Адрес: 1113, София, бул. „Акад.Г.Бончев”, бл.1

e-mail: andreiIKIT@space.bas.bg 